REVISIONES

\title{
Endemic Juniperus gracilior varieties of the Hispaniola island, tree taxa of environmental and economic relevance and a valuable phytochemical source
}

\author{
Variedades de Juniperus gracilior endémicas de la Hispaniola, \\ taxones con relevancia económica y ambiental y valiosas fuentes de fitoquímicos
}

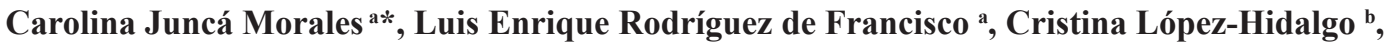 \\ Rafael M Navarro Cerrillo c, Omar Paíno Perdomo a , Jesús Valentín Jorrín Novo d \\ *Corresponding author: a Instituto Tecnólogico de Santo Domingo, Basic and Environmental Sciences Area, \\ Santo Domingo, Dominican Republic, tel.: 809-567-9271 ext.: 608,1074736@est.intec.edu.do, \\ luis.defrancisco@intec.edu.do,omar.perdomo@intec.edu.do, carolinajuncam@yahoo.com \\ ${ }^{\mathrm{b}}$ Universidad de Oviedo, Faculty of Biology, Department of Organisms and Systems Biology, \\ Oviedo, Spain, lopezhcristina@uniovi.es \\ c Universidad de Córdoba, Department of Forestry Engineering, Córdoba, Spain, rmnavarro@uco.es \\ d Universidad de Córdoba, Department of Biochemistry and Molecular Biology, \\ Córdoba, Spain, bf1jonoj@uco.es
}

\begin{abstract}
SUMMARY
The Juniperus genus has long been used and studied for the chemical components of its aerial parts (leaves, bark, twigs) and their bioactivity. Nevertheless, these studies and their compilation have been primarily focused on Europe and North America distributed taxa, leaving the knowledge and economic potential of the endangered Caribbean taxa highly underrepresented in the literature. Although, these conifers have been barely investigated for their bioactive compounds, bibliography does indicate the presence of potent antitumoral, anti-inflammatory and antimicrobial molecules such as deoxypodophyllotoxin, podophyllotoxin, amentoflavone and widdrol. Additional phytochemical potential can also be inferred from the systematical essential oil studies of the taxa, the only source of chemical composition information on most of them. These investigations can aid in the narrowing down of the possible bioactivities their lipidic extracts may possess, while also providing clues for the bioassays necessary to confirm them. This review aims to compile the known information on the usage, bioactivity and chemical composition of the Hispaniolian J. gracilior varieties and their phylogenetically proximal taxa (J. gracilior var. saxicola, J. barbadensis and J. bermudiana), to propitiate more holistic and in depth chemical studies on these potential phytochemical sources, in turn providing an economical incentive for their conservation.
\end{abstract}

Key words: bioactive compounds, conservation, metabolomics, Caribbean.

\section{RESUMEN}

El género Juniperus ha sido utilizado y estudiado a lo largo de los años por la bioactividad de los compuestos fitoquímicos encontrados en sus tejidos (hojas, corteza, ramas). Mayoritariamente, dichas investigaciones y las recopilaciones de estas se han centrado en taxones distribuidos en Europa y América del Norte, dejando de lado la investigación y potencial económico de otros, como los caribeños, que actualmente se encuentran en peligro de extinción. Aunque los compuestos bioactivos de los últimos apenas han sido estudiados, en la literatura se reportan potentes moléculas antitumorales, antiinflamatorias y antimicrobianas como la desoxipodofilotoxina, podofilotoxina, amentoflavona y el widdrol en su composición. De igual manera, investigaciones fitoquímicas realizadas a sus aceites esenciales con objetivo taxonómico, que en muchos casos representan la única fuente de información química de estos Juniperus del Caribe, permiten inferir propiedades bioactivas adicionales de los mismos, lo que resalta su posible potencial. Este trabajo tuvo como objetivo recopilar la información conocida sobre el uso, la bioactividad y la composición química de las variedades de $J$. gracilior endémicas de la Hispaniola y sus taxones filogenéticamente cercanos (J. gracilior var. saxicola, J. barbadensis y J. bermudiana), para propiciar futuros estudios holísticos y exhaustivos de los metabolitos encontrados en estas posibles fuentes de compuestos fitoquímicos, proporcionando así un incentivo económico para su conservación.

Palabras clave: compuestos bioactivos, conservación, metabolómica, Caribe. 


\section{INTRODUCTION}

The Juniperus genus, commonly referred to as "cedars" in English and "enebro" or "sabina" in Spanish, comprises 67 species and 37 varieties (Adams 2014). From Tibetan mountains to tropical islands, juniper trees and shrubs are distributed in all continents except Antarctica. Of the 114 taxa, seven are localized in the Caribbean archipelago: $J$. gracilior var. gracilior (Pilger), J. gracilior var. ekmanii (Florin) R. P. Adams and J. gracilior var. urbaniana (Pilger et Ekman), endemic to Hispaniola island, J. gracilior var. saxicola (Britton et P. Wilson), endemic to Cuba, $J$. barbadensis var. barbadensis (Linnaeus), endemic to St. Lucia, J. barbadensis var. lucayana (Britton) R. P. Adams, found in Cuba, Bahamas and Jamaica, and J. bermudiana (Linnaeus), endemic to Bermuda (Adams 2014).

Species within the Juniperus genus have long been used for therapeutic purposes and known for their pharmacological properties (Seca et al. 2015). Their chemical components have also been utilized in food production as flavoring (Falasca et al. 2013) and could be used as food preservatives (Lesjak et al. 2017). Additionally, polyphenols and other compounds of the genre provide an essence potentially used in the cosmetic (Rangel et al. 2018), while also being interesting for pharmaceutical industries, with individual bioactive compounds being potential leads for new drug development (Kwon et al. 2010, Tavares and Seca 2018). Although these investigations have been gathered by review articles such as those written by Seca and Silva (2006), Seca and collaborators (2015) and Tavares and Seca (2018), the economic value and potential of the critically endangered $J$. gracilior (Pilger) Hispaniolan varieties have not been described (García et al. 2016). This review aims to emphasize the current and potential use of bioactive chemical components from J. gracilior by compiling pertinent information of phylogenetically proximal taxa (J. gracilior var. saxicola, J. barbadensis var. barbadensis, J. barbadensis var. lucayana and J. bermudiana). Information available in Dominican governmental reports and overall bibliography was consulted to provide a comprehensive review for $J$. gracilior chemical components and to highlight its economic potential as a way of guaranteeing this species conservation (Newton 2008).

\section{JUNIPERS IN THE HISPANIOLA ISLAND, ENVIRONMENTAL SITUATION AND ECONOMIC IMPORTANCE}

The Hispaniola is a Caribbean island comprised of two countries, the Dominican Republic and Haiti. The forest cover of the island is reported to be $\sim 2 \%$ on the west side (Haiti) and $\sim 41 \%$ on the east (Dominican Republic) (Posner et al. 2010, MIMARENA 2019). These habitats have a biodiverse flora with an array of endemic species, being especially true in the mountainous territory, which holds pine forests and hundreds of endemic species, including its most representative conifer species Pinus occidentalis (Swartz), Podocarpus hispaniolensis (Laubenfels) and $J$. gracilior (Posner et al. 2010, Cano-Ortiz et al. 2016, MIMARENA 2019). The islands' juniper (Juniperus) varieties (figure 1) inhabit elevations between 1,000 and 2,550 meters above sea level, with locations (figure 2) differing among varieties. J. gracilior var. gracilior inhabits Dominican mountainous ranges such as Sierra Martín García, Cordillera Central, Sierra de Bahoruco (Zanoni and Mejia 1986) and Sierra de Neiba (Familia et al. 2019), while J. gracilior var. ekmanii is found in the Haitian Massif de la Selle, Massif du Nord (Adams 1983) and the Dominican Sierra de Bahoruco (Adams 2014), and J. gracilior var. urbaniana occupies Haitian Massif de la Selle and Dominican Sierra de Bahoruco (Adams 2014).

Although these forests represent an environmental and economic benefit for the island, since colonial times, unsustainable depletion of their vegetation has resulted in significant forest reduction and in the critical endangerment of many endemic taxa (Posner et al. 2010, García et al. 2016). The three $J$. gracilior varieties have been jeopardized due to this anthropic intervention. Mainly, as a result of continuous community and farmland establishment in and tree logging, which locals undertake to economically sustain themselves and supply the demand of the fragrant ekmanii and gracilior wood, coveted in the territory (Adams 1983, Peguero and Clase 2015). Since in the 1980s, reforestation efforts have been made on the island, however, the endemic junipers have not taken a significant role in this rehabilitation (Williams 2011, MIMARENA 2019). Two organizations, Dominican National Botanical Garden [2007 - ongoing] and Arche aux Plantes [2013 2018], have in recent times, undertaken projects which aim to conserve and propagate seeds of the species (Conservatoire Botanique National de Brest 2017, Mattana et al. 2017). Nevertheless, these have not sufficed to augment populations enough to reduce extinction risk.

\section{BIOACTIVE PREPARATIONS AND EXTRACTS FROM CARIBBEAN JUNIPERS}

Juniperus species have been used in traditional or folk medicine even when the scientific bases of their mode of action and the chemicals behind their bioactivity are unknown. Within the genus, J. oxycedrus and J. communis are the most studied in terms of their pharmacological and therapeutic effects (Tavares and Seca 2018). The list of referenced properties pertaining the extracts of their aerial parts is ample, including antifungal (Ortiz et al. 2004), insect repellent (Jacobson 2018), antitussive (Carpenter et al. 2012), antihypertensive (Usmanghani et al. 1997), diuretic (Öztürk et al. 2011), antiseptic (Khare 2007), antiinflammatory (Khare 2007, Jazayeri et al. 2014), carminative (Usmanghani et al. 1997, Khan et al. 2012) hypoglycemic (Orhan et al. 2012), antioxidant (Jazayeri et al. 2014) and abortive (Öztürk et al. 2011), while also being 

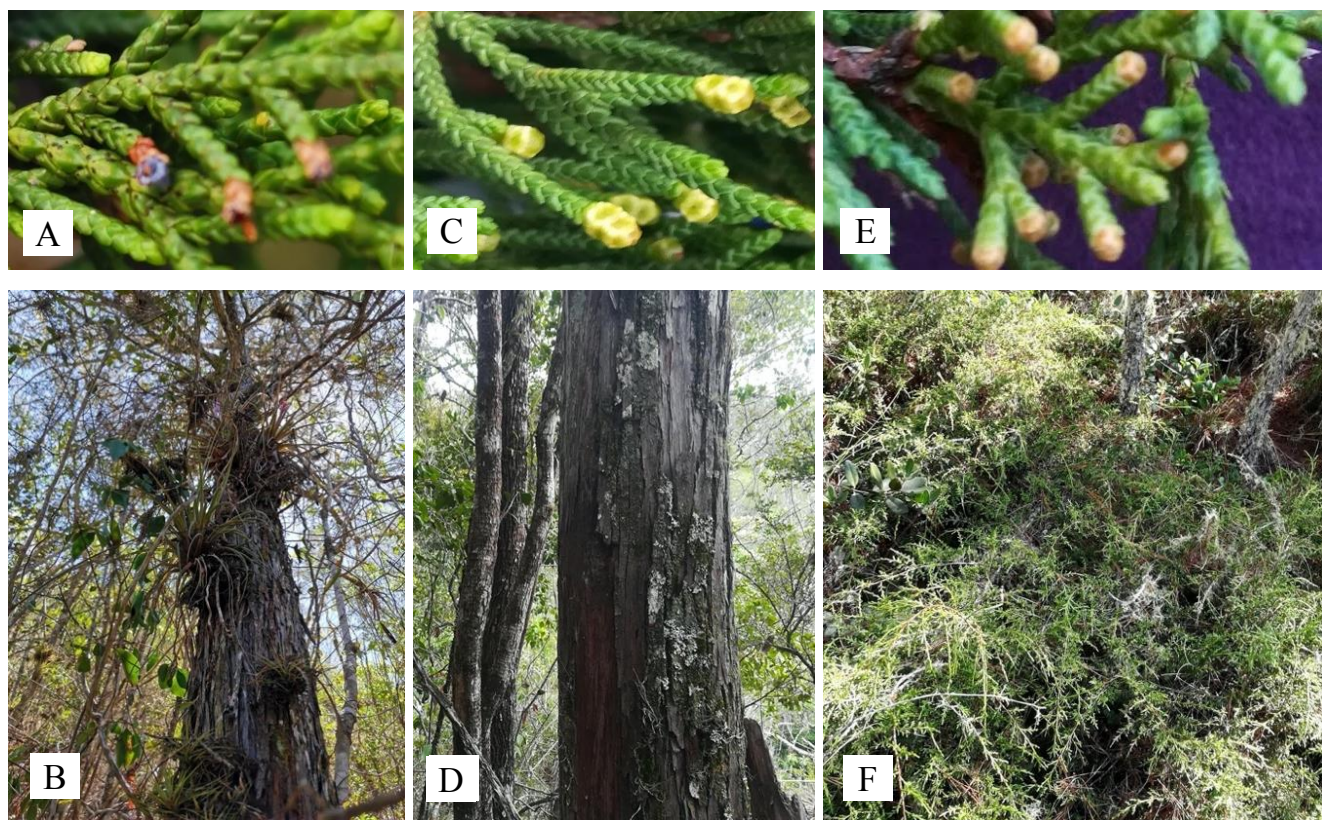

Figure 1. Morphology of the three endemic J. gracilior varieties. A) Leaves and berry (purple structure), gracilior variety; B) gracilior variety tree; C) Leaves and cones (yellow structures), ekmanii variety; D) Trunk, ekmanii variety; E) Leaves and cones (yellowish structures) urbaniana variety; F) urbaniana variety shrub. Photo credits: Carolina Juncá (A, B) and Amelia Mateo (C, D, E, F).

Morfología de las tres variedades endémicas de J. gracilior. A) Hojas y fruto (estructura morada), variedad gracilior; B) Árbol, variedad gracilior; C) Hojas y conos (estructuras amarillas), variedad ekmanii; D) Tronco, variedad ekmanii; E) Hojas y conos (estructuras amarillas), variedad urbaniana; F) Arbusto, variedad urbaniana. Fotografías tomadas por Carolina Juncá (A, B) y Amelia Mateo (C, D, E, F).

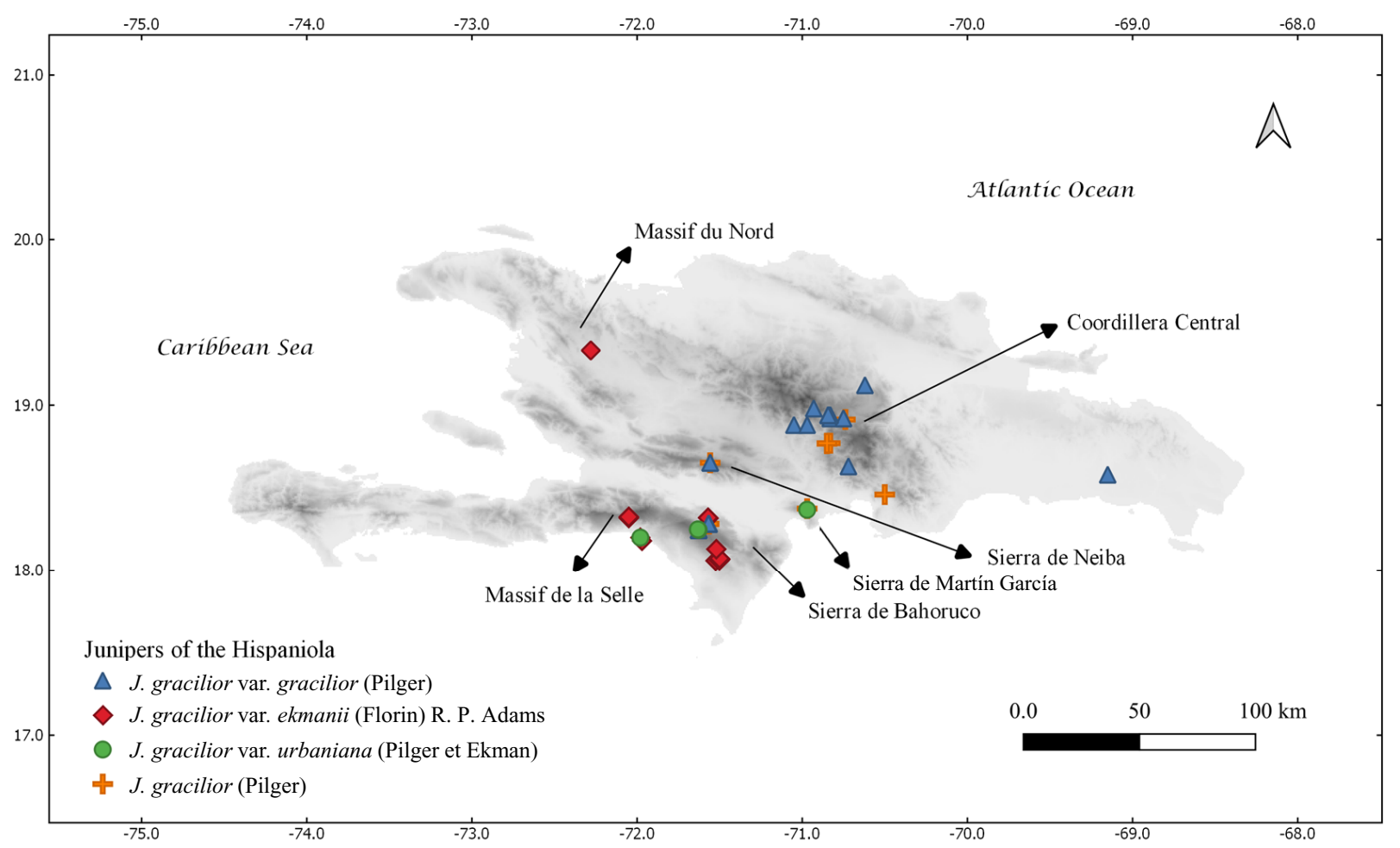

Figure 2. Distribution of $J$. gracilior in Hispaniola Island. Sightings obtained from GBIF (GBIFab) and field trips organized by the Instituto Tecnológico de Santo Domingo (INTEC) between 2018 and 2019 (unpublished data).

Distribución de las variedades de J. gracilior en la isla de la Hispaniola. Avistamientos obtenidos de GBIF (GBIFab) y de viajes de campo organizados por el Instituto Tecnológico de Santo Domingo (INTEC) entre 2018 y 2019 (datos no publicados). 
used as remedies for urinary infection (Grosourdy 1864), cold, bronchitis (Öztürk et al. 2011) diabetes (Orhan et al. 2012, Carpenter et al. 2012), asthma (Khan et al. 2012), urticaria, dysentery, leucorrhea (But et al. 1997), haemorrhoids (Öztürk et al. 2011) and tuberculosis (Omari et al. 2019).

Although a vast array of information can be found for taxa in territories outside the Caribbean, for the four species that do inhabit these islands, historical uses bibliography is scarce. Only $J$. bermudiana preparations have been reported to be utilized in precolonial times for medicinal and culinary purposes (Wolsak 2017). Nevertheless, studies have reported that Caribbean junipers have been employed in treating urinary infections and have also presented cytotoxic, antioxidant, antibacterial and pest repellency properties (Fitzgerald et al. 1957, Grosourdy 1864, Martínez et al. 1996, Jacobson 2018). A list of the bioactivities attributed to Caribbean juniper preparations can be found in table 1.

\section{JUNIPERS AS A SOURCE OF PHYTOCHEMICALS AND BIOACTIVE COMPOUNDS}

Besides the interest shown for its bioactive preparations, Juniperus genus has been investigated for phytochemicals such as abietatriene derivatives, widdrol, deoxypodophyllotoxin, amentoflavone, dehydroabietic acid and limonene, whose properties could aid in new drug and product development (Kwon et al. 2010, Seca et al. 2015, Tavares and Seca 2018, Mukhtar et al. 2018). Among these taxa, those form the Caribbean are known to possess potent antitumor molecules against human cancer cell lines. For instance, in these taxa, researchers have been able to identify deoxypodophyllotoxin (Tammami et al. 1977), considered to be one of the most cytotoxic metabolites in the genus (Tavares and Seca 2018), and its biosynthetic product podophyllotoxin (Renouard et al. 2011), whose concentrations in Caribbean taxa have made $J$. bermudiana its second most important productor (Bazaldúa et al. 2019). Chemical studies have also led to the detection of other useful compounds such as amentoflavone (Gadek and Quinn 1985), a flavonoid with properties such as antitumoral (Chen et al. 2015) antimicrobial (Coulerie et al. 2013), antioxidant (Li et al. 2014), anti-inflammatory (Abdallah et al. 2015), antidiabetic (Laishram et al. 2015) and diuretic (Aguilar et al. 2015, Tavares and Seca 2018). Additionally, widdrol has been found, a lignin reported to be antiproliferative against adenocarcinoma HT29 cells (Kwon et al. 2010), lipolysis inducer in mice adipocytes (Jeong et al. 2015) and inhibitor of B. cinerea growth (Ortiz et al. 2005). Moreover, other compounds with antifungal activity against $B$. cinerea have been identified and evaluated, including 15-hidroxy- $\alpha$-pseudowiddrene, cedrol, 3-hydroxypseudowiddran-6(7)-en-4-ol, 12-hydroxywiddrol, sandaracopimaric acid and $\alpha$-bisabolol (Ortiz et al. 2004, 2005).

Besides the aforementioned compounds, which have been uncovered and bioassayed, other molecules have been reported as part of the essential oil characterization of Caribbean junipers. A list summarizing reported compounds can be found in table 2. Said characterization of foliar terpenes was used to determine the systematic relationship among the taxa utilizing gas chromatography coupled with mass spectrometry (GC-MS) (Adams 1983, 2000). These studies revealed that in Hispaniolan varieties, bornyl acetate accounts for more than $30 \%$ of their essential oil terpene content, followed by terpinen-4-ol, sabinene, limonene in J. gracilior var. gracilior, limonene and sabinene in $J$. gracilior var. ekmanii, and sabinene, limonene and terpinen-4-ol in J. gracilior var. urbaniana (Adams 1983, 2000). Junipers found in Caribbean territories other than this island do not possess bornyl acetate as their major essential oil component. Perhaps the best example is the Cuban J. gracilior variety, saxicola, which

Table 1. Reported bioactivities of Caribbean taxa extracts.

Bioactividades reportadas para los extractos de los taxones caribeños

\begin{tabular}{|c|c|c|c|}
\hline Taxa & Extract (organ) & Bioactivity & Reference \\
\hline J. bermudiana & $\begin{array}{l}\text { Ethanolic extract } \\
\text { (twigs and leaves) }\end{array}$ & $\begin{array}{l}\text { Inhibitory activity toward the P-388 } \\
\text { lymphocytic leukemia (PS) cell line and } \\
\text { cytotoxic activity toward human epidermoid } \\
\text { carcinoma of the nasopharynx (KB) }\end{array}$ & Tammami et al. 1977 \\
\hline J. barbadensis var. lucayana & Acetone extract (wood) & $\begin{array}{l}\text { Inhibition of the fungus Botrytis cinerea } \\
\text { growth }\end{array}$ & Ortiz et al. 2004 \\
\hline J. barbadensis var. lucayana & Ethanolic extract (wood) & Inhibition of the fungus $B$. cinerea growth & Ortiz et al. 2004 \\
\hline J. barbadensis var. lucayana & Aqueous extract (stem) & $\begin{array}{l}\text { Antimicrobial activity against } \\
\text { Staphylococcus aureus }\end{array}$ & Martínez et al. 1996 \\
\hline J. barbadensis var. barbadensis & Aqueous extract (shoots) & Treats urinary system pathologies & Grosourdy 1864 \\
\hline
\end{tabular}




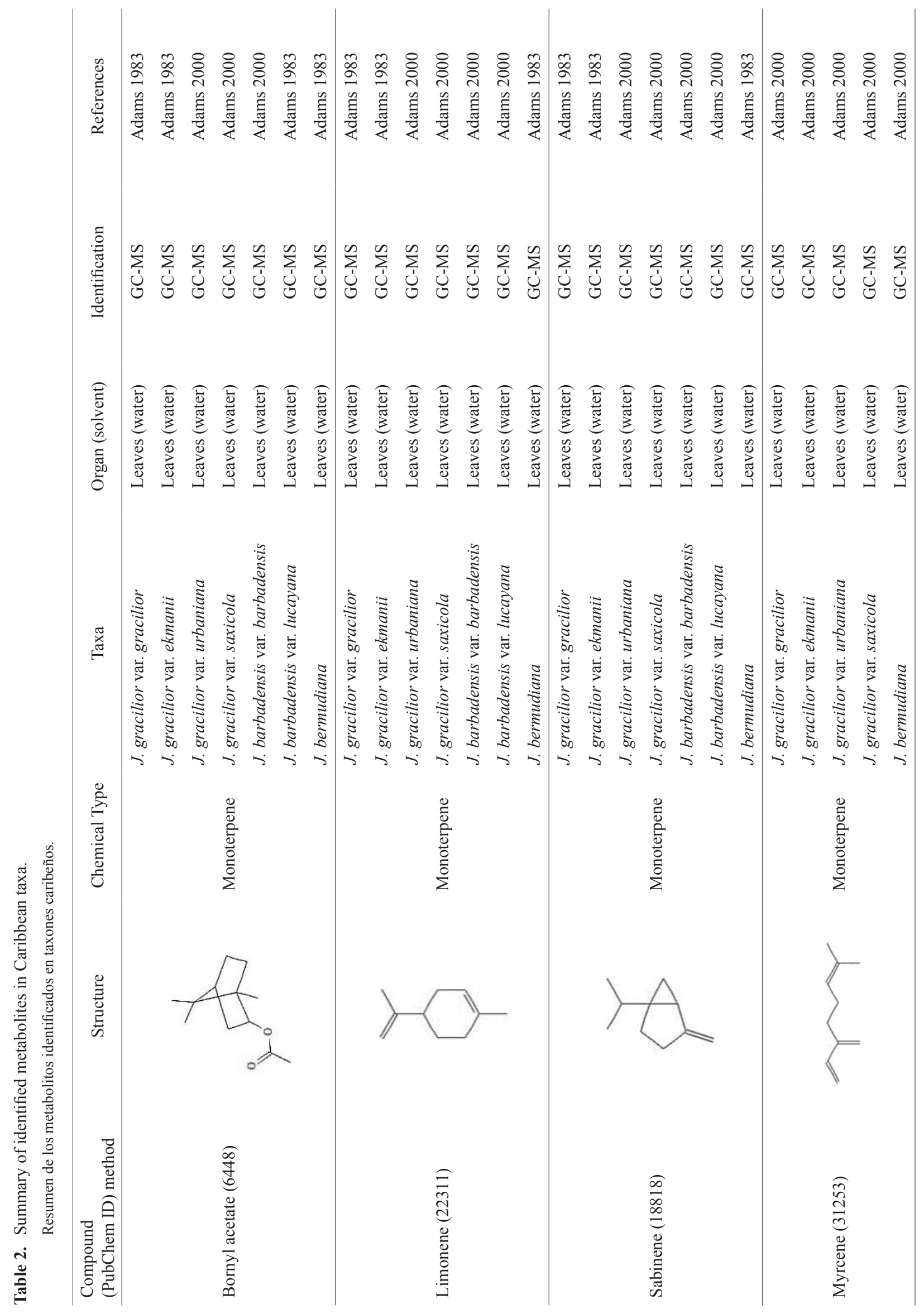




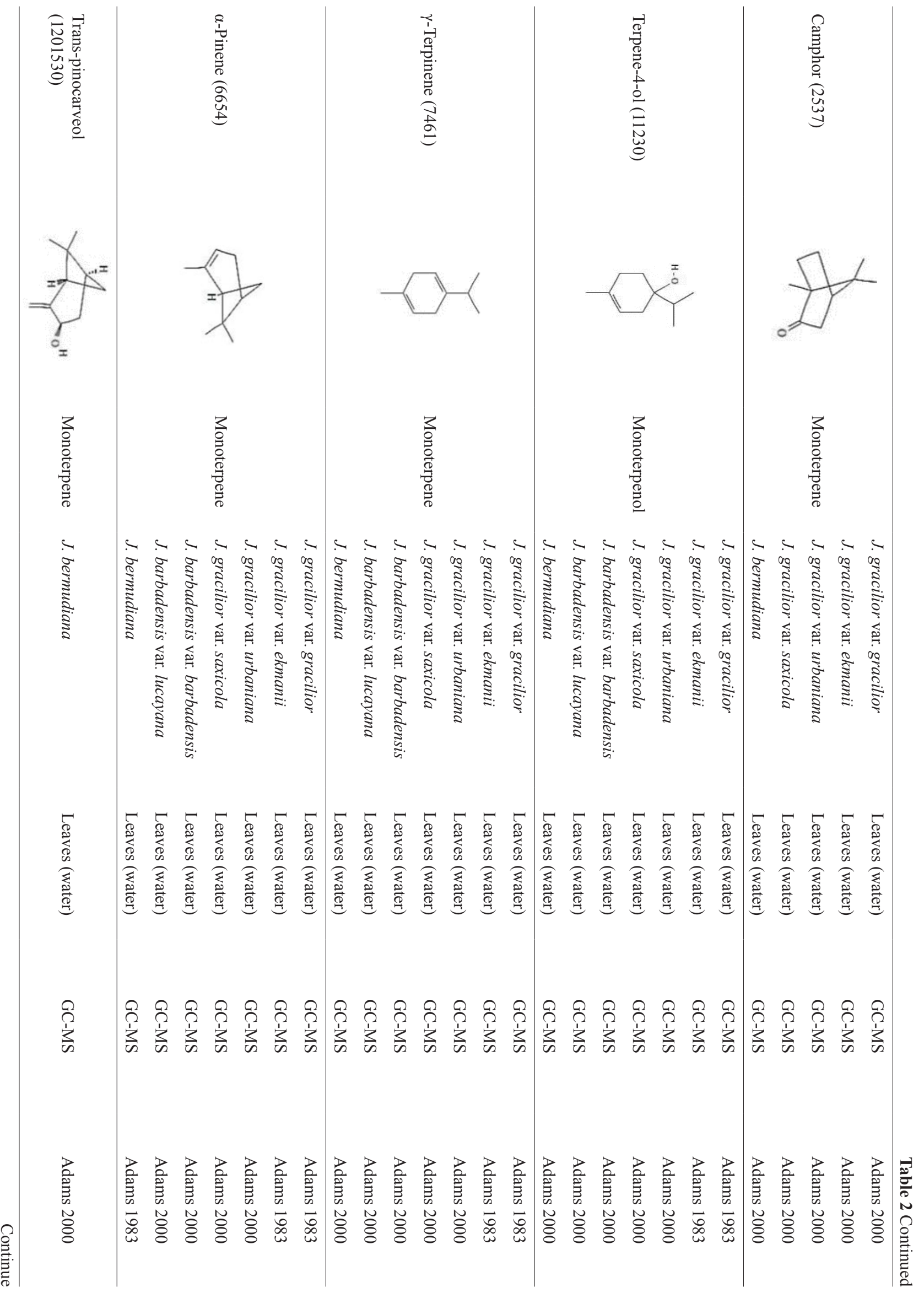




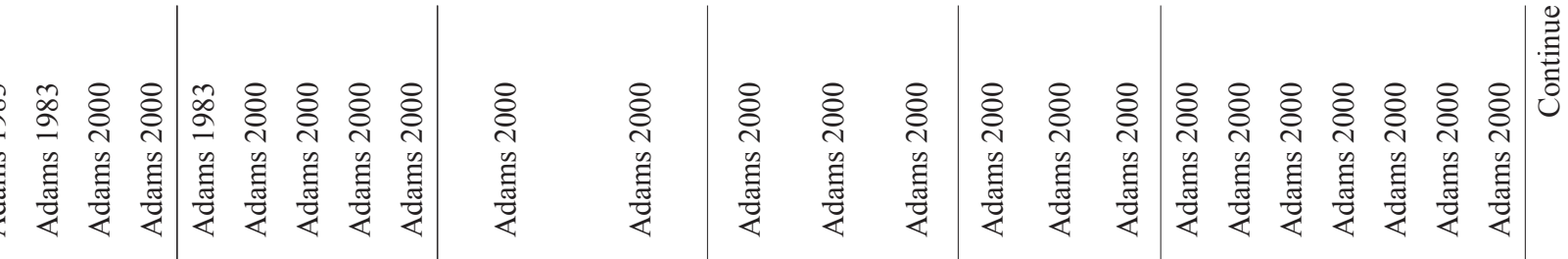

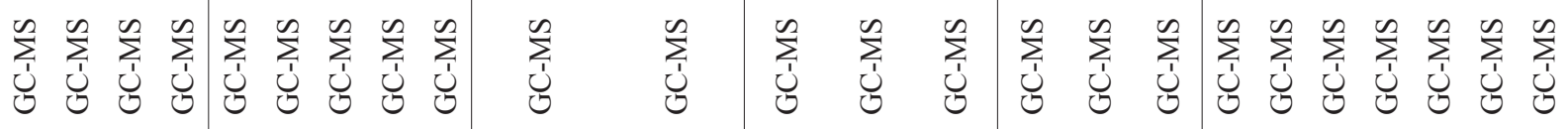

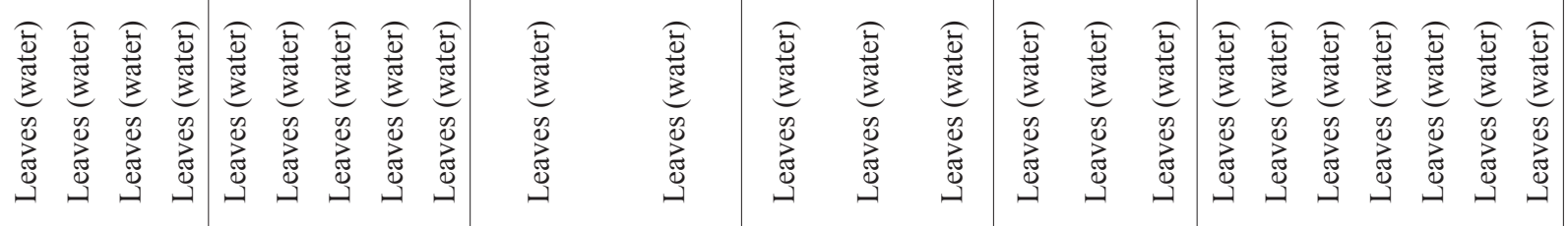

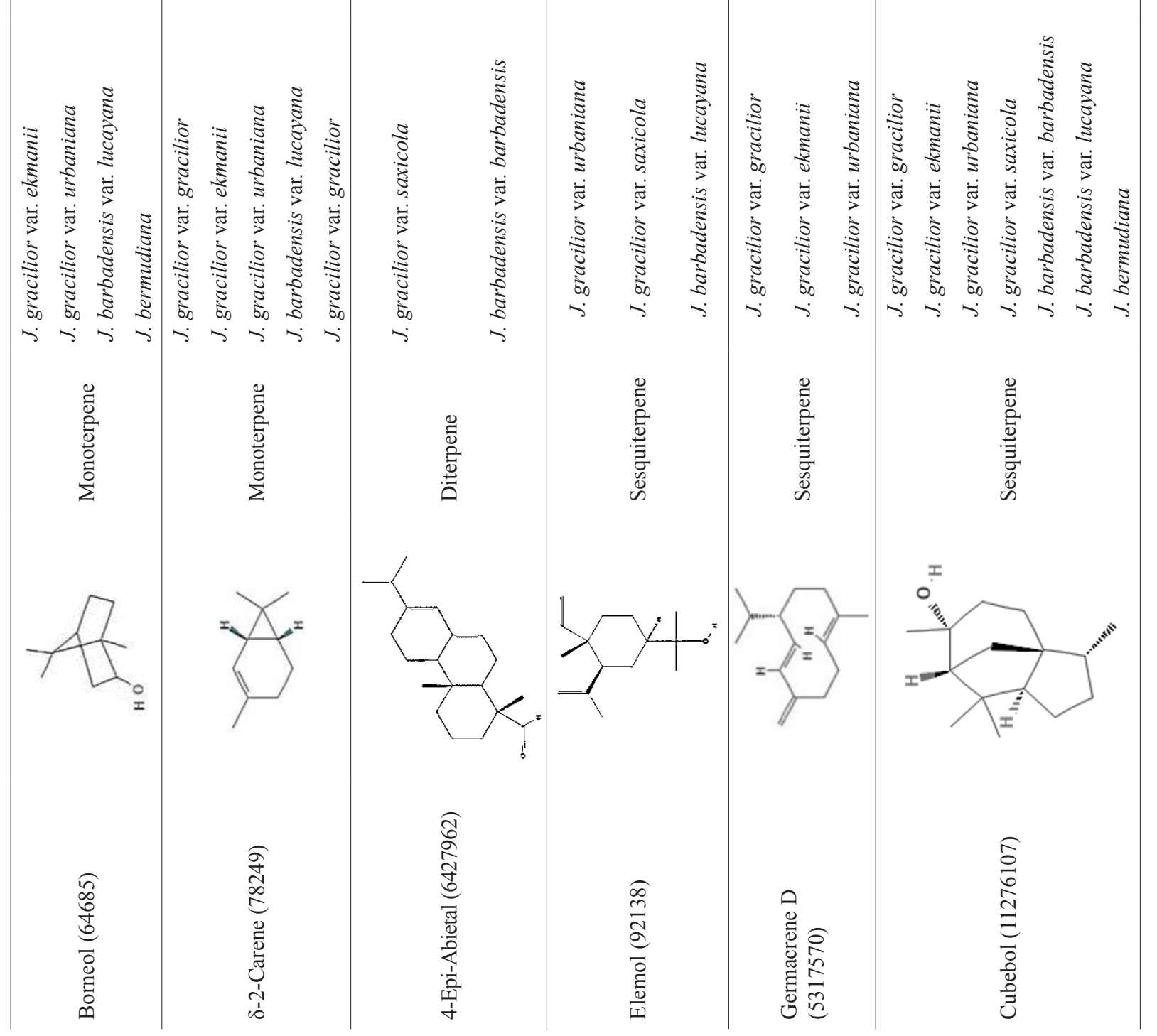




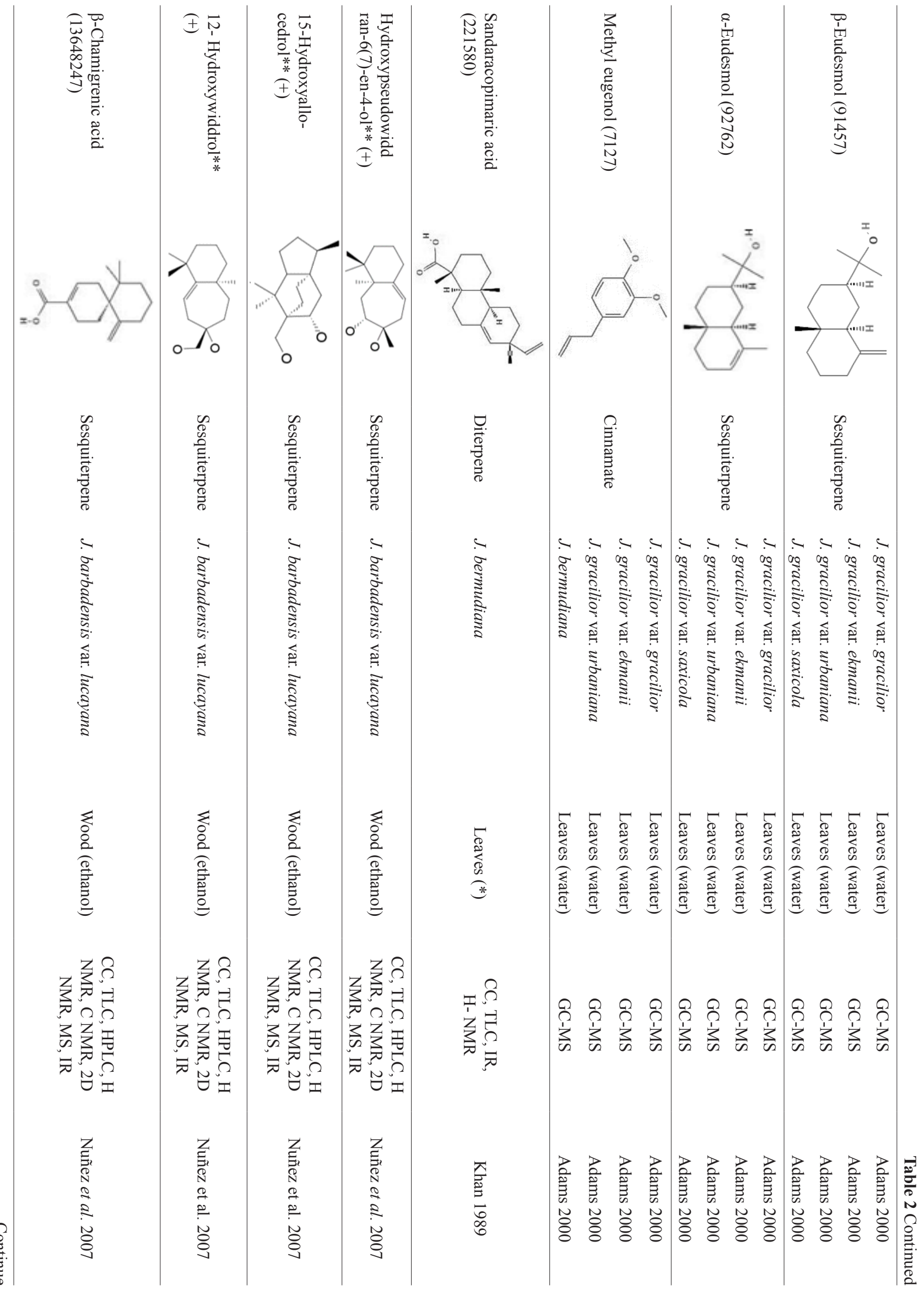




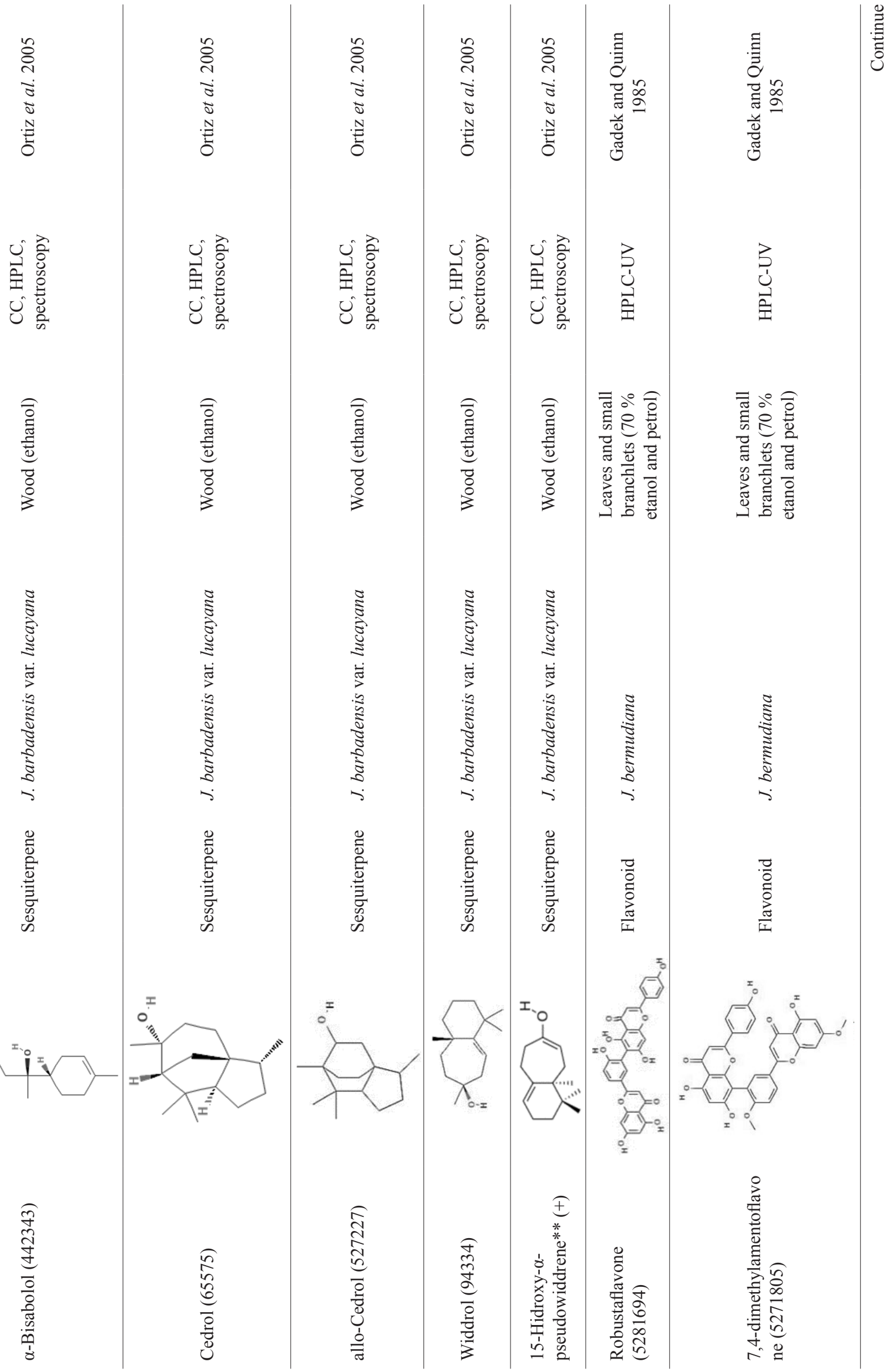




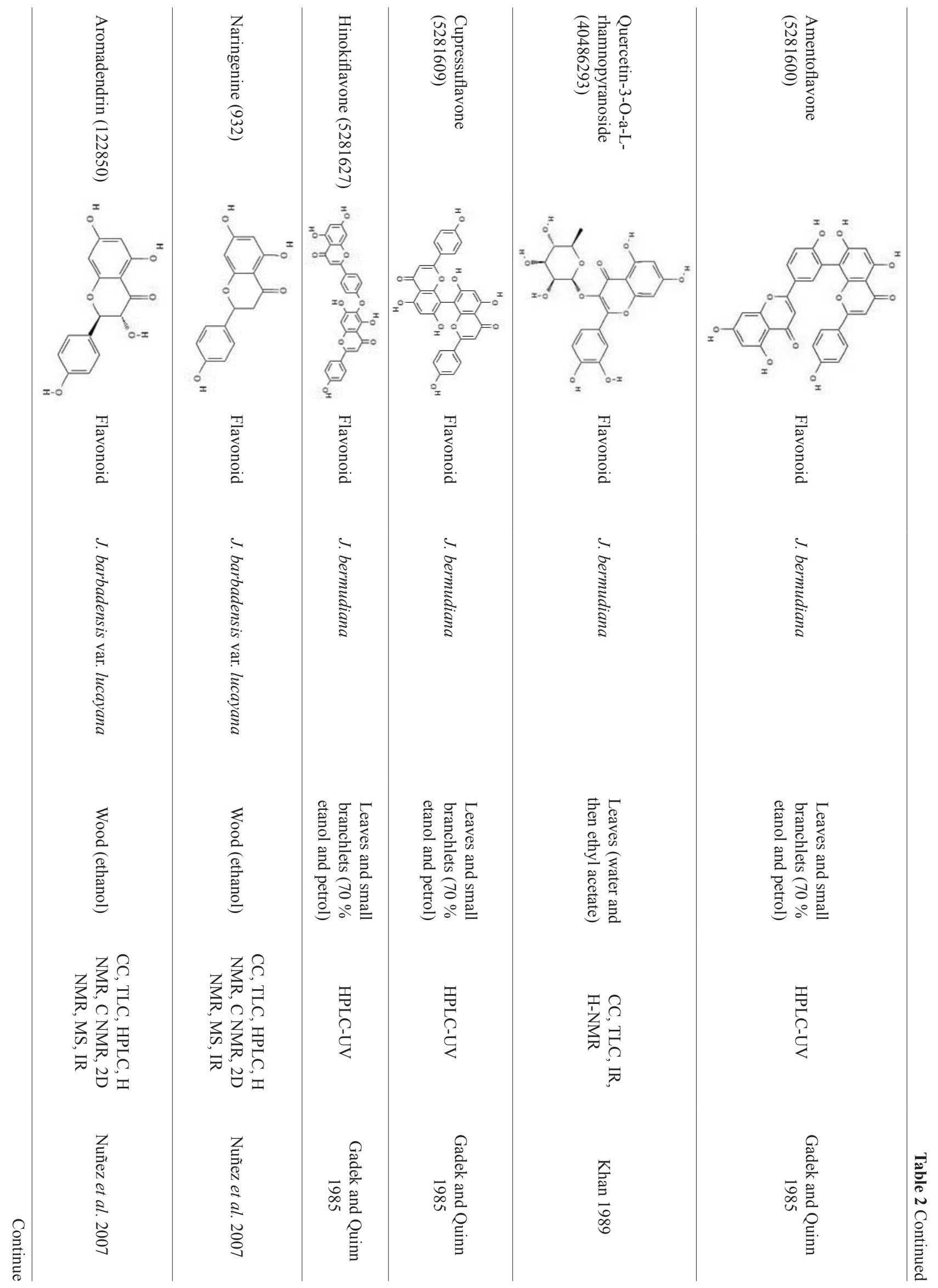




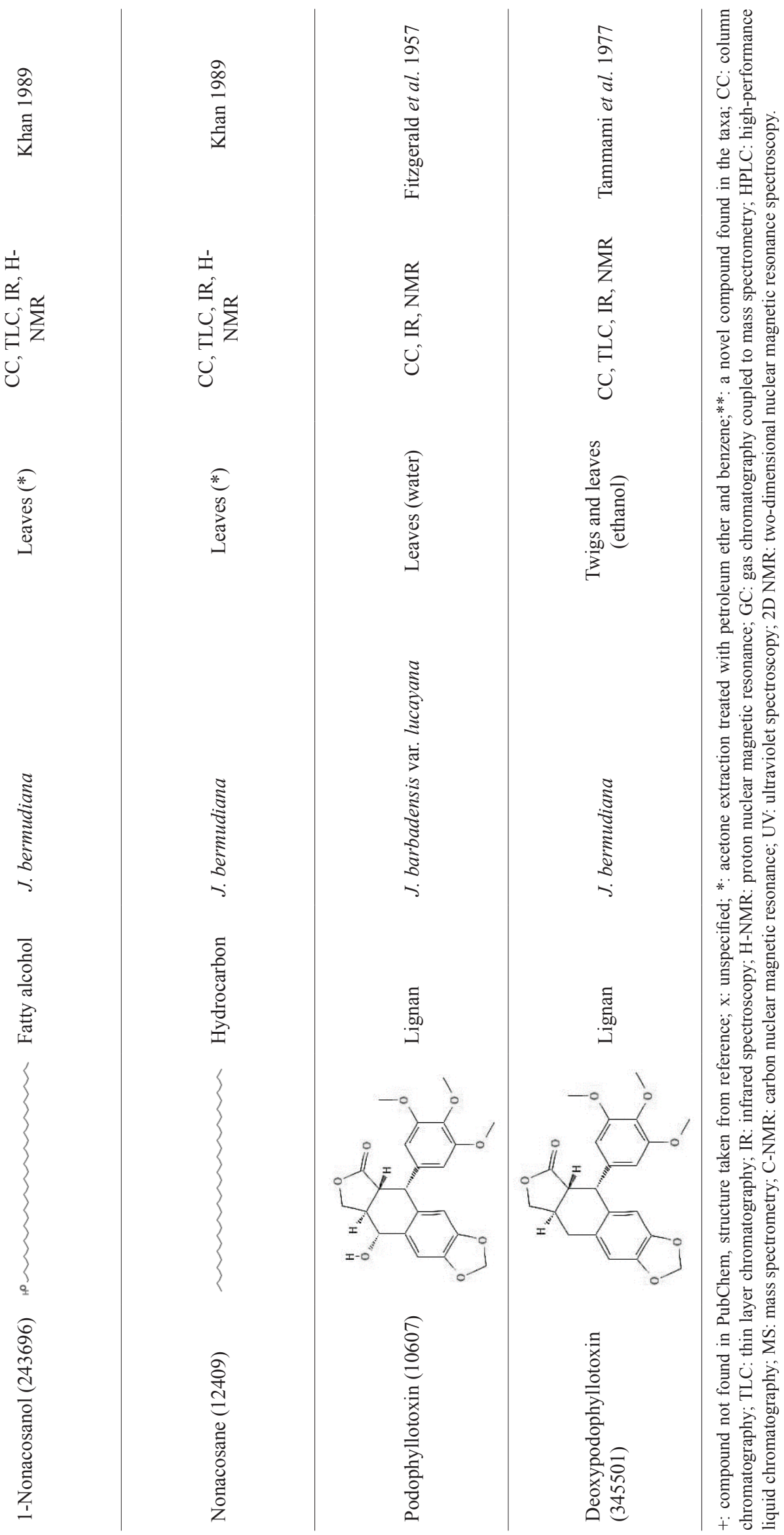


has 4-epi-abietal, elemol and sabinene as its majoritary terpenes, only having $0.3 \%$ bornyl acetate in its oil (Adams 2000). As for the remaining Caribbean junipers: J. barbadensis var. barbadensis has limonene, sabinene, terpinen4-ol, and $\alpha$-pinene, while J. bermudiana, has limonene, $\alpha$-pinene and camphor, and Juniperus barbadensis var. lucayana $\alpha$-pinene, limonene and sabinene as their major essential oil terpenes (Adams 2000). The bioactive potential of the pure form of some of these majority essential oil compounds can be consulted in table 3 .

In general, literature describing the chemical composition and usage of the Caribbean taxa is concentrated on $J$. bermudiana and $J$. barbadensis var. lucayana (Fitzgerald et al. 1957, Tammami et al. 1977, Gadek and Quinn 1985, Khan 1989, Martínez 1996, Ortiz et al. 2004, 2005, Nuñez et al. 2007, Renouard et al. 2011, Wolsak 2017). The other taxa are only mentioned in studies about insect repellency and are not reported their traditional usage and medicine bibliography in their respective countries (Jacobson 2018). Studies involving a holistic chemical characterization of these taxa with subsequent bioactivity assays need to be conducted to elucidate the phytochemical composition and potential usage of these conifers. The mentioned pure form bioactivities of these essential oil terpenes, although not accounting for their synergistic or antagonistic interactions with other compounds, might present a lead for future bioactivity assays of the taxa.

\section{FUTURE DIRECTION IN INVESTIGATING JUNIPERS PHYTOCHEMICALS, THE METABOLOMICS APPROACH}

As mentioned above, the full phytochemical composition of endemic Caribbean Juniperus spp. is widely understudied. This information, being of pivotal importance for botanical, conservation, and pharmacological purposes, is crucial for bioprospecting studies of the species to increase its protection locally. Currently, among the characterization of living organisms, metabolomics is playing a key role, either alone or in combination with guided biological activity assays (Wishart 2016). Metabolomics is the systematic study, identification and quantification, of the metabolites in an organism at a specific moment in time (metabolome) (Tugizimana et al. 2013). And while phylogenetic lineages can help select new taxon targets for bioactivity studies, metabolomics can help identify structurally related metabolites conserved throughout evolution that might be of interest to the investigator (Mawalagedera et al. 2019).

In a broad sense, the steps of a metabolomics study (figure 3) are as follows: material sampling and extraction, extract analyses or data acquisition, statistical analyses and metabolite identification (Choi and Verpoorte 2014). How these steps are performed ultimately depends on the investigator's objective and approach (targeted or untargeted). A targeted approach identifies and quantifies a few known and predetermined metabolites, while an untargeted one aims to study all the known and unknown metabolites present in a sample (Tugizimana et al. 2013).

For metabolite identification and quantification, different extraction solvents and methodologies can be employed. According to the analytical platform used, metabolomic studies mainly belong to two groups, MS- and RMN- based. These can be utilized in parallel or combination to other classic protocols of thin layer, liquid or gas chromatography, spectrometry and spectroscopy (Nuñez et al. 2007). The platforms employed in the identification of chemical components of the Juniperus Caribbean clade can be found in table 2. As a whole, this genus has had compounds from leaf, wood and berry extract characterized, with most of these investigations being designed with

Table 3. Essential oil majority terpenes of Hispaniolian junipers and their pure form bioactivities.

Bioactividades de las formas puras de los terpenoides mayoritarios en el aceite esencial de los Juniperus de la Hispaniola.

\begin{tabular}{|c|c|c|}
\hline Terpene & Bioactivities & References \\
\hline Bornyl acetate & $\begin{array}{l}\text { Antioxidant and anti-inflammatory. Acaricidal against Derma- } \\
\text { tophagoides farinae, D. pteronyssinus and Tyrophagus putres- } \\
\text { centiae. Strong fumigant with contact toxicity against Liposcelis } \\
\text { bostrychophila and Tribolium castaneum. }\end{array}$ & $\begin{array}{l}\text { Lee } \text { et al. 2009, Chen et al. 2014, Yang et al. } \\
\text { 2014, Feng et al. } 2019\end{array}$ \\
\hline Terpinen-4-ol & $\begin{array}{l}\text { Anti-demodectic and antimicrobial against Streptococcus mutans } \\
\text { and Lactobacillus acidophilus. Significant growth inhibitor of co- } \\
\text { lorectal, pancreatic, prostate and gastric cancer cells. }\end{array}$ & $\begin{array}{l}\text { Shapira et al. } 2016 \text {, Bordini et al. } 2018 \text {, Che- } \\
\text { ung et al. } 2018\end{array}$ \\
\hline Sabinene & $\begin{array}{l}\text { Strong antioxidant activity and antibacterial activity against } E s- \\
\text { cherichia coli. }\end{array}$ & Sharma et al. 2019 \\
\hline Limonene & $\begin{array}{l}\text { Antiviral, anti-inflammatory, and antibacterial. Antitumor capabi- } \\
\text { lities for gastric lung, pancreatic, mammary, liver and colon tumor } \\
\text { models. }\end{array}$ & $\begin{array}{l}\text { Stayrook et al. 1997, Yoon et al. 2010, Jia et } \\
\text { al. 2013, Astani and Schnitzler 2014, Zhang } \\
\text { et al. 2014, Miller et al. 2015, Yu et al. 2018, } \\
\text { Hafidh et al. 2018, Han et al. } 2019\end{array}$ \\
\hline
\end{tabular}




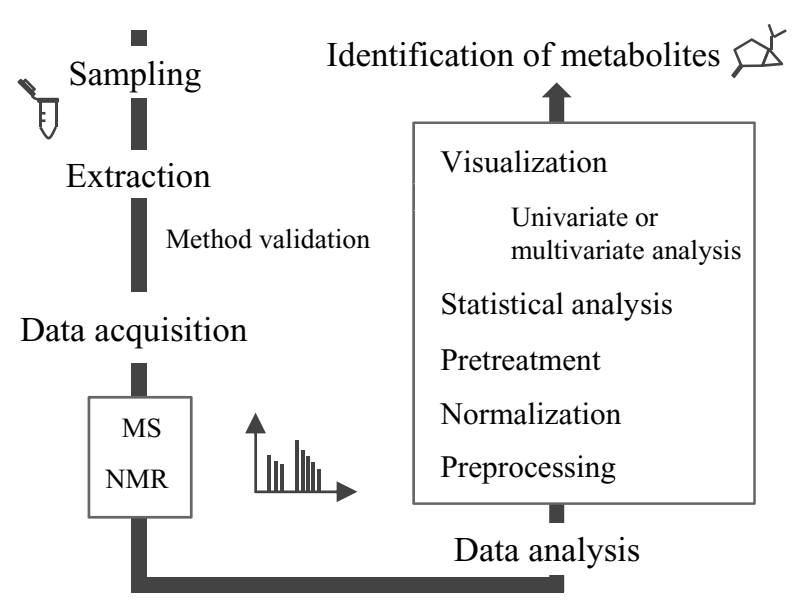

Figure 3. General metabolomics workflow.

Flujo de trabajo general para un experimento de metabolómica.

a targeted approach to specific chemical groups (Adams 2000, Renouard et al. 2011, Falasca et al. 2013, Rangel et al. 2018). For the identification of novel and/or useful bioactive compounds of $J$. gracilior and other Caribbean junipers, an untargeted approach focused on a larger range of metabolites including uninvestigated chemical groups such as polyphenols, known antioxidants, anti-mutagenic and antitumor compounds (Rangel et al. 2018), might need to be used.

\section{ACKNOWLEDGEMENTS}

This research was supported by Fondo Nacional de Innovación y Desarrollo Científico-Tecnológico (FONDOCYT) with the project number 2016-2017-214.

\section{REFERENCES}

Abdallah HM, FM Almowallad, A Esmat, IA Shehata, EA AbdelSattar. 2015. Anti-inflammatory activity of flavonoids from Chrozophora tinctoria. Phytochemistry Letters 13: 74-80. DOI: https://doi.org/10.1016/j.phytol.2015.05.008

Adams RP. 1983. The Junipers (Juniperus, Cupressaceae) of Hispaniola Comparison with other Caribbean species and among collections from Hispaniola. Moscosoa 2(1): 77-89.

Adams RP. 2000. Systematics of smooth leaf margin Juniperus of the Western hemisphere based on leaf essential oils and RAPD DNA fingerprinting. Biochemical Systematics and Ecology 28(2): 149-162. DOI: https://doi.org/10.1016/ S0305-1978(99)00047-2

Adams RP. 2014. Junipers of the world: The genus Juniperus. Indiana, United States of America. Trafford Publishing. 422 p.

Aguilar MI, WV Benítez, A Colín, R Bye, R Ríos-Gómez, F Calzada. 2015. Evaluation of the diuretic activity in two Mexican medicinal species: Selaginella nothohybrida and Selaginella lepidophylla and its effects with ciclooxigenases inhibitors. Journal of Ethnopharmacology 163: 167-
172. DOI: https://doi.org/10.1016/j.jep.2015.01.031

Astani A, P Schnitzler. 2014. Antiviral activity of monoterpenes beta-pinene and limonene against herpes simplex virus in vitro. Iranian Journal of Microbiology 6(3): 149-155.

Bazaldúa C, A Cardoso-Taketa, G Trejo-Tapia, B Camacho-Diaz, J Arellano, E Ventura-Zapata, ML Villarreal. 2019. Improving the production of podophyllotoxin in hairy roots of Hyptis suaveolens induced from regenerated plantlets. PloS One 14(9): e0222464. DOI: https://doi.org/10.1371/journal.pone.0222464

Bordini E, CC Tonon, RS Francisconi, F Magalhães, P Huacho, TL Bedran, S Pratavieira, LC Spolidorio, DP Spolidorio. 2018. Antimicrobial effects of terpinen-4-ol against oral pathogens and its capacity for the modulation of gene expression. Biofouling 34(7): 815-825. DOI: https://doi.org/1 $\underline{0.1080 / 08927014.2018 .1504926}$

But PPH, T Kimura, JX Gue, CK Sung. 1997. International collation of traditional and folk medicine: Northeast Asia Part II. Singapore, Singapore. World Scientific Publishing. 248 p.

Cano-Ortiz A, C Musarella, J Fuentes, C Gomes, E Cano. 2016. Distribution patterns of endemic flora to define hotspots on Hispaniola. Systematics and Biodiversity 14(3): 261-275. DOI: $\underline{\text { https://doi.org/10.1080/14772000.2015.1135195 }}$

Carpenter CD, T O’Neill, N Picot, JA Johnson, GA Robichaud, D Webster, CA Gray. 2012. Anti-mycobacterial natural products from the Canadian medicinal plant Juniperus communis. Journal of Ethnopharmacology 143(2): 695-700. DOI: https://doi.org/10.1016/j.jep.2012.07.035

Chen JH, WL Chen, YC Liu. 2015. Amentoflavone Induces Antiangiogenic and Anti-metastatic Effects Through Suppression of NF-кB Activation in MCF-7 cells. Anticancer Research 35(12): 6685-6693.

Chen N, G Sun, X Yuan, J Hou, Q Wu, LW Soromou, H Feng. 2014. Inhibition of lung inflammatory responses by born$\mathrm{yl}$ acetate is correlated with regulation of myeloperoxidase activity. Journal of Surgical Research 186(1): 436-445. DOI: https://doi.org/10.1016/j.jss.2013.09.003

Cheung I, AL Xue, A Kim, K Ammundsen, M Wang, JP Craig. 2018. In vitro anti-demodectic effects and terpinen-4-ol content of commercial eyelid cleansers. Contactlens \& Anterior Eye 41(6): 513-517. DOI: https://doi.org/10.1016/j. clae.2018.08.003

Choi Y, R Verpoorte. 2014. Metabolomics: What You See is What You Extract. Phytochemical Analysis 25(4): 289-290. DOI: https://doi.org/10.1002/pca.2513

Conservatoire Botanique National de Brest. 2017. Sauvetage du Genévrier d'Ekman et préservation de la flore de la Forêt des Pins à Haïti. Consulted Jun. 15 2020. Available in http://www.cbnbrest.fr/nos-actions-phares/107

Coulerie P, M Nour, A Maciuk, C Eydoux, JC Guillemot, N Lebouvier, E Hnawia, K Leblanc, G Lewin, B Canard, B Figadère. 2013. Structure-activity relationship study of biflavonoids on the Dengue virus polymerase DENV-NS5 RdRp. Planta Medica 79(14): 1313-1318. DOI: https://doi. org/10.1055/s-0033-1350672

Estévez A. 2019. Memoria Institucional: Ano 2019. Consulted Apr. 25 2020. Available in https://ambiente.gob.do/wpcontent/uploads/2020/01/Memoria-Institucional-2019.pdf

Falasca A, D Melck, D Paris, G Saviano, A Motta, M Iorizzi. 2013. Seasonal changes in the metabolic fingerprint of Juniperus communis L. berry extracts by $1 \mathrm{H}$ NMR-based 
metabolomics. Metabolomics 10(1): 165-174. DOI: https:// doi.org/10.1007/s11306-013-0566-1

Familia L, T Montilla, T Clase, G Santana, A Guerrero. 2019. Cambios en la cobertura boscosa del bosque nublado en la sierra de Neiba, República Dominicana. Ciencia, Ambiente y Clima 2(1): 7-22. DOI: https://doi.org/10.22206/ cac.2019.v2i1.pp7-22

Feng YX, Y Wang, ZY Chen, SS Guo, CX You, SS Du. 2019. Efficacy of bornyl acetate and camphene from Valeriana officinalis essential oil against two storage insects. Environmental Science and Pollution Research 26(16): 1615716165. DOI: https://doi.org/10.1007/s11356-019-05035-y

Fitzgerald DB, JL Hartwell, J Leiter. 1957. Distribution of the Tumor-Damaging Lignans among Conifers. Journal of the National Cancer Institute 18(1): 83-99. DOI: https://doi. org/10.1093/jnci/18.1.83

Gadek P, C Quinn. 1985. Biflavones of the subfamily Cupressoideae, Cupressaceae. Phytochemistry 24(2): 267-272. DOI: https://doi.org/10.1016/S0031-9422(00)83535-9

García R, B Peguero, F Jiménez, A Veloz, T Clase. 2016. Lista Roja de la Flora Vascular en República Dominicana. Jardín Botánico Nacional Dr. Rafael Ma. Moscoso. Consulted May 14 2020. Available in http://www.jbn.gob.do/transparencia/index.php/publicaciones-t?start $=20$

GBIF (Global Biodiversity Information Facility, DK). 18872020a. GBIF Occurrence Database (online). Consulted Apr. 21 2020. Available in https://doi.org/10.15468/d1.4mv9mb

GBIF (Global Biodiversity Information Facility, DK). 18872020b. GBIF Occurrence Database (online). Consulted Apr. 21 2020. Available in https://doi.org/10.15468/dl.r8bn5a

Grosourdy R. 1864. El médico botánico criollo: Tomo 3. Paris, France. Francisco Brachet. 416 p.

Hafidh RR, SZ Hussein, MQ MalAllah, AS Abdulamir, F Abu Bakar. 2018. A High-throughput Quantitative Expression Analysis of Cancer-related Genes in Human HepG2 Cells in Response to Limonene, a Potential Anticancer Agent. Current Cancer Drug Targets 18(8): 807-815. DOI: https:// doi.org/10.2174/1568009617666171114144236

Han Y, Z Sun, W Chen. 2019. Antimicrobial Susceptibility and Antibacterial Mechanism of Limonene against Listeria monocytogenes. Molecules 25(1): 33. DOI: https://doi. org/10.3390/molecules 25010033

Jacobson M. 2018. Glossary Of Plant Derived Insect Deterrents. Florida, United States of America. CRC Press. 219 p.

Jazayeri SB, A Amanlou, N Ghanadian, P Pasalar, M Amanlou. 2014. Apreliminary investigation of anticholinesterase activity of some Iranian medicinal plants commonly used in traditional medicine. DARU Journal of Pharmaceutical Sciences 22(1): 17. DOI: https://doi.org/10.1186/2008-2231-22-17

Jeong HY, HJ Yun, BW Kim, EW Lee, HJ Kwon. 2015. Widdrolinduced lipolysis is mediated by PKC and MEK/ERK in 3T3-L1 adipocytes. Molecular and Cellular Biochemistry 410(1-2): 247-257. DOI: https://doi.org/10.1007/s11010$\underline{015-2558-0}$

Jia SS, GP Xi, M Zhang, YB Chen, B Lei, XS Dong, YM Yang. 2013. Induction of apoptosis by D-limonene is mediated by inactivation of Akt in LS174T human colon cancer cells. Oncology Reports 29(1): 349-354. DOI: https://doi. org/10.3892/or.2012.2093

Khan I. 1989. Chemistry of Natural Products. PhD Thesis. Aligarh, India. Department of Chemistry, Aligarh Muslim Uni- versity. $450 \mathrm{p}$.

Khan M. A Khan, A Najeeb-ur-Rehman, A Gilani. 2012. Pharmacological explanation for the medicinal use of Juniperus excelsa in hyperactive gastrointestinal and respiratory disorders. Journal of Natural Medicines 66(2): 292-301. DOI: https://doi.org/10.1007/s11418-011-0605-Z

Khare CP. 2007. Indian medicinal plants: An illustrated dictionary. Berlin/Heidelberg, Germany. Springer Verlag. 900 p.

Kim S, J Chen, T Cheng, A Gindulyte, J He, S He, Q Li, BA Shoemaker, P Thiessen, B Yu, L Zaslavsky, J Zhang, EE Bolton. 2019. PubChem 2019 update: improved access to chemical data. Nucleic Acids Research 47(D1): D1102D1109. DOI: https://doi.org/10.1093/nar/gky1033

Kwon HJ, EW Lee, YK Hong, HJ Yun, BW Kim. 2010. Widdrol from Juniperus chinensis induces apoptosis in human colon adenocarcinoma HT29 cells. Biotechnology and Bioprocess Engineering 15(1): 167-172. DOI: https://doi.org/10.1007/ $\underline{\text { s12257-009-0154-4 }}$

Laishram S, Y Sheikh, D Moirangthem, L Deb, B Pal, N Talukdar, J Borah. 2015. Anti-diabetic molecules from Cycas pectinata Griff. traditionally used by the Maiba-Maibi. Phytomedicine 22(1): 23-26. DOI: https://doi.org/10.1016/j.phymed.2014.10.007

Lee CH, JM Park, HY Song, EY Jeong, HS Lee. 2009. Acaricidal activities of major constituents of essential oil of Juniperus chinensis leaves against house dust and stored food mites. Journal of Food Protection 72(8): 1686-1691. DOI: https:// doi.org/10.4315/0362-028X-72.8.1686

Lesjak M, I Beara, D Orčić, G Anačkov, P Knežević, Z Mrkonjić N Mimica-Dukić. 2017. Bioactivity and chemical profiling of the Juniperus excelsa, which support its usage as a food preservative and nutraceutical. International Journal of Food Properties 20(S2): 1652-1663. DOI: https://doi.org/ $\underline{10.1080 / 10942912.2017 .1352598}$

Li X, L Wang, W Han, W Mai, L Han, D Chen. 2014. Amentoflavone Protects against Hydroxyl Radical-induced DNA Damage via Antioxidant Mechanism. Turkish Journal of Biochemistry 39(1): 30-36. DOI: https://doi.org/10.5505/ tib.2014.65882

Martínez M, J Betancourt, N Alonso-González, A Jauregui. 1996. Screening of some Cuban medicinal plants for antimicrobial activity. Journal of Ethnopharmacology 52(3): 171174. DOI: https://doi.org/10.1016/0378-8741(96)01405-5

Mattana E, K Manger, M Way, T Ulian, R García, W Encarnacion, T Clase, B Peguero, F Jimenez. 2017. A new seed bank for Hispaniola to support the conservation and sustainable use of the Caribbean native flora. Oryx 51(3): 394-395. DOI: https://doi.org/10.1017/s0030605317000692

Mawalagedera S, D Callahan, A Gaskett, N Rønsted, M Symonds. 2019. Combining Evolutionary Inference and Metabolomics to Identify Plants with Medicinal Potential. Frontiers In Ecology And Evolution 7: 267. DOI: https:// doi.org/10.3389/fevo.2019.00267

Miller JA, K Pappan, PA Thompson, EJ Want, AP Siskos, HC Keun, J Wulff, C Hu, JE Lang, HH Chow. 2015. Plasma metabolomic profiles of breast cancer patients after shortterm limonene intervention. Cancer Prevention Research 8(1): 86-93. DOI: https://doi.org/10.1158/1940-6207. CAPR-14-0100

MIMARENA (Ministerio de Medio Ambiente y Recursos Naturales, DO). 2019. Sexto Informe Nacional de Biodiver- 
sidad de la República Dominicana. Ministerio de Medio Ambiente y Recursos Naturales. Consulted Mar. 302020. Available in https://ambiente.gob.do/download/382/sextoinforme-de-biodiversidad/18975/sexto-informe-nacionalsobre-biodiversidad-chm.pdf

Mukhtar Y, M Adu-Frimpong, X Xu, J Yu. 2018. Biochemical significance of limonene and its metabolites: future prospects for designing and developing highly potent anticancer drugs. Bioscience Reports 38(6): BSR20181253. DOI: $\underline{\text { https://doi.org/10.1042/BSR20181253 }}$

Newton A. 2008. Conservation of tree species through sustainable use: How can it be achieved in practice? Oryx 42(2): 195205. DOI: https://doi.org/10.1017/S003060530800759X

Nuñez YO, IS Salabarria, IG Collado, R Hernández-Galán. 2007. Sesquiterpenes from the wood of Juniperus lucayana. Phytochemistry 68(19): 2409-2414. DOI: https://doi. org/10.1016/j.phytochem.2007.05.030

Omari KE, M Hamze, S Alwan, M Osman, C Jama, NE Chihib. 2019. In-vitro evaluation of the antibacterial activity of the essential oils of Micromeria barbata, Eucalyptus globulus and Juniperus excelsa against strains of Mycobacterium tuberculosis (including MDR), Mycobacterium kansasii and Mycobacterium gordonae. Journal of Infection and Public Health 12(5): 615-618. DOI: https://doi.org/10.1016/j. jiph.2019.01.058

Orhan N, M Aslan, M Pekcan, DD Orhan, Bedir E, Ergun F. 2012. Identification of hypoglycaemic compounds from berries of Juniperus oxycedrus subsp. oxycedrus through bioactivity guided isolation technique. Journal of Ethnopharmacology 139(1): 110-118. DOI: https://doi.org/10.1016/j. jep.2011.10.027

Ortiz Núñez Y, I González Collado, R Hernández-Galán, IS Salabarría, Y Rodríguez, MA Alvarez, Y Lorenzo. 2004. Actividad fungicida de cuatro especies Cubanas de plantas sobre Botrytis cinerea Pers. Estudio Fitoquímico. Revista Cubana de Química 16: 204-206.

Ortiz Y, R Hernández-Galán, I Spengler, Y Rodríguez, R Sánchez, IG Collado. 2005. Studies on fungicides constituents of Juniperus lucayana Britton. Biotransformation by Botrytis cinerea and Colletotrichum gloeosporioides. Revista Cubana de Quimica 17(3): 225.

Öztürk M, İ Tümen, A Uğur, F Aydoğmuş-Öztürk, G Topçu. 2011. Evaluation of fruit extracts of six Turkish Juniperus species for their antioxidant, anticholinesterase and antimicrobial activities. Journal of the Science of Food and Agriculture 91(5): 867-876. DOI: https://doi.org/10.1002/jsfa.4258

Peguero B, T Clase. 2015. Composición y estructura de la vegetación en Cerro Angola, San José de las Matas, provincia Santiago, República Dominicana. Moscosoa 19: 37-69.

Posner S, GA Michel, JR Toussaint. 2010. Haiti Biodiversity and Tropical Forest Assessment. USDA Forest Service. Consulted Apr. 25 2020. Available in https://usaidgems.org/Documents/FAA\&Regs/FAA118119LAC/Haiti_FAA_118-119 Dec 2010\%20(1).pdf

Rangel ML, JA Guerrero-Analco, JL Monribot-Villanueva, AL Kiel-Martínez, S Avendaño-Reyes, JPD Abad, I BonillaLanda, R Dávalos-Sotelo, JL Olivares-Romero, G Angeles. 2018. Anatomical and chemical characteristics of leaves and branches of Juniperus deppeana var. deppeana $(\mathrm{Cu}$ pressaceae): A potential source of raw materials for the perfume and sweet candies industries. Industrial Crops and
Products 113: 50-54. DOI: https://doi.org/10.1016/j.indcrop.2017.12.046

Renouard S, T Lopez, O Hendrawati, P Dupre, J Doussot, A Falguieres, C Ferroud, D Hagege, F Lamblin, E Laine, C Hano. 2011. Podophyllotoxin and deoxypodophyllotoxin in Juniperus bermudiana and 12 other Juniperus species: Optimization of extraction, method validation, and quantification. Journal of Agricultural and Food Chemistry 59(15): 8101-8107. DOI: https://doi.org/10.1021/jf201410p

Seca A, A Silva. 2006. The chemical composition of the Juniperus Genus (1970-2004). In Govil JN, VK Singh, R Bhardwaj eds. Recent Progress in Medicinal Plants. Texas, United States of America. Studium Press LLC. p. 401-522.

Seca A, PC Pinto, A Silva. 2015. The Current Status of Bioactive Metabolites from the Genus Juniperus. In Gupta VK ed. Bioactive Phytochemicals: Perspectives for Modern Medicine. Jammu, India. Daya Publishing House. p. 365-408.

Shapira S, S Pleban, D Kazanov, P Tirosh, N Arber. 2016. Terpinen-4-ol: A Novel and Promising Therapeutic Agent for $\mathrm{Hu}-$ man Gastrointestinal Cancers. PloS One 11(6): e0156540. DOI: https://doi.org/10.1371/journal.pone.0156540

Sharma S, J Gupta, PK Prabhakar, P Gupta, P Solanki, A Rajput. 2019. Phytochemical Repurposing of Natural Molecule: Sabinene for Identification of Novel Therapeutic Benefits Using in Silico and in Vitro Approaches. Assay and Drug Development Technologies 17(8): 339-351. DOI: https:// doi.org/10.1089/adt.2019.939

Stayrook KR, JH McKinzie, YD Burke, YA Burke, PL Crowell. 1997. Induction of the apoptosis-promoting protein Bak by perillyl alcohol in pancreatic ductal adenocarcinoma relative to untransformed ductal epithelial cells. Carcinogenesis 18(8): 1655-1658. DOI: https://doi.org/10.1093/ carcin/18.8.1655

Tammami B, SJ Torrance, JR Cole. 1977. Antitumor agent from Juniperus bermudiana (Pinaceae): Deoxypodophyllotoxin. Phytochemistry 16(7): 1100-1101. DOI: https://doi. org/10.1016/S0031-9422(00)86752-7

Tavares W, A Seca. 2018. The Current Status of the Pharmaceutical Potential of Juniperus L. Metabolites. Medicines 5(3): 81. DOI: https://doi.org/10.3390/medicines5030081

Tugizimana F, L Piater, I Dubery. 2013. Plant metabolomics: A new frontier in phytochemical analysis. South African Journal of Science 109(5-6): 1-11. DOI: https://doi.org/10.1590/ sajs.2013/20120005

Usmanghani K, A Saeed, MT Alam. 1997. Indusyunic medicine: Traditional medicine of herbal animal and mineral origin in Pakistan. Karachi, Pakistán. University of Karachi Press. $591 \mathrm{p}$.

Williams V. 2011. A Case Study of the Desertification of Haiti. Journal Of Sustainable Development 4(3): 20-31. DOI: https://doi.org/10.5539/jsd.v4n3p20

Wishart DS. 2016. Emerging applications of metabolomics in drug discovery and precision medicine. Nature Reviews Drug Discovery 15(7): 473-484. DOI: https://doi. org/10.1038/nrd.2016.32

Wolsak AS. 2017. Of fishpots, bonnets, and wine: the cultural history of the Bermuda palmetto. Master's Thesis. Vancouver, United States of America. Faculty of Graduate and Postdoctoral Studies, University of British Columbia. 245 p. DOI: https://doi.org/10.14288/1.0362882

Yang H, R Zhao, H Chen, P Jia, L Bao, H Tang. 2014. Bornyl 
acetate has an anti-inflammatory effect in human chondrocytes via induction of IL-11. IUBMB Life 66(12): 854-859. https://doi.org/10.1002/iub.1338

Yoon WJ, NH Lee, CG Hyun. 2010. Limonene suppresses lipopolysaccharide induced production of nitric oxide, prostaglandin E2, and pro-inflammatory cytokines in RAW 264.7 macrophages. Journal of Oleo Science 59(8): 415-421. DOI: $\underline{\text { https://doi.org/10.5650/jos.59.415 }}$

Yu X, H Lin, Y Wang, W Lv, S Zhang, Y Qian, X Deng, N Feng, H Yu, B. 2018. Qian. d-limonene exhibits antitumor acti- vity by inducing autophagy and apoptosis in lung cancer. Onco Targets Ther 4(11): 1833-1847. DOI: https://doi. org/10.2147/OTT.S155716

Zanoni TA, M Mejia. 1986. Notas sobre la flora de la isla Española II. Moscosoa 4: 105-132

Zhang XZ, L Wang, DW Liu, GY Tang, HY Zhang. 2014. Synergistic inhibitory effect of berberine and d-limonene on human gastric carcinoma cell line MGC803. Journal of Medicinal Food 17(9): 955-962. DOI: https://doi.org/10.1089/ jmf.2013.2967

Recibido: 15/07/20

Aceptado: 26/10/20 